\title{
The Effect of Cilofungin (LY 121019) in Combination with Amphotericin B or Flucytosine Against Candida Species
}

\section{Die Wirkung von Cilofungin (LY 121019) in Kombination mit Amphotericin B oder Flucytosin auf Candida-Arten}

\author{
A.N. Bulo, Suzanne F. Bradley and Carol A. Kauffman \\ Division of Infectious Diseases, Department of Internal Medicine, Veterans Administration Medical \\ Center, Amn Arbor, Michingan, U.S.A. \\ University of Michigan Medical School, Ann Arbor, Michigan, U.S.A.
}

Key words: Candida - antifungals - cilofungin - amphotericin B - flucytosine - synergism Schlüsselwörter: Candida - Antimykotika - Cilofungin - Amphotericin B - Flucytosin Synergismus

Summary: Cilofungin was combined with amphotericin B or flucytosine to determine if synergistic inhibition or killing occurred against 50 strains of various Candida species. Synergistic inhibition of growth occurred only once with amphotericin B and cilofungin and only 2 times with flucytosine and cilofungin. Synergistic killing occurred in 5 strains with the amphotericin B-cilofungin combination and in 7 strains with the flucytosine-cilofungin combination. Antagonism occurred frequently with both the amphotericin B-cilofungin and the flucytosine-cilofungin combinations.

Zusammenfassung: Cilofungin wurde mit Amphotericin B oder Flucytosin kombiniert, um eine etwaige synergistische Wachstumshemmung oder Inaktivierung von 50 Stämmen unterschiedlicher Candi$d a$-Arten zu untersuchen. Eine synergistische Wachstumshemmung wurde nur ein- mal mit Amphotericin B und Cilofungin und zweimal mit Flucytosin und Cilofungin beobachtet. Eine synergistische Abtötung trat an 5 Stämmen mit der Amphotericin B-Cilofungin- und an 7 Stämmen mit der Flucytosin-Cilofungin-Kombination auf. Häufiger wurden bei beiden Kombinationen Antagonismen gefunden.

\section{Introduction}

LY 121019, now known as cilofungin, is a new antifungal agent which has been shown to be effective against several Candida species, especially Candida albicans and $C$. tropicalis, the major causes of disseminated candidosis $(2-4,7,8)$. It has been suggested that the drug may be effective against $C$. $k r u-$ sei and $C$. glabrata although the minimum inhibitory concentration (MIC) is generally higher for these organisms $(2,7)$. Against 
other Candida strains and other yeast-like fungi cilofungin does not appear to be as active (2).

Currently, the drug of choice for serious Candida infections is amphotericin B, despite its serious toxicity (6). In some instances, flucytosine can be added to synergistically treat Candidainfections (5). Combination therapy with flucytosine and amphotericin B and Flucytosinehas the added advantage of allowing reduction of the daily amphotericin B and Flucytosinedose and thus decreasing the toxicity (1). We tested cilofungin with amphotericin B and Flucytosineand with flucytosine in vitro to determine if synergism might occur when this new anti-Candida drug was combined with the drugs used commonly in the treatment of candidosis.

\section{Materials and Methods}

\section{Fungi}

Fifty clinical isolates of Candida species maintained in our laboratory were examined. Organisms grown overnight on Sabouraud dextrose agar (Difco, Inc., Detroit, MI) were suspended in $0.9 \%$ saline to a concentration of $2 \times 10^{7} \mathrm{CFU} / \mathrm{ml},(0.55$ optical density reading at $660 \mathrm{~nm}$ ). The final inoculum was prepared in either Sabouraud dextrose broth (Difco, Inc.), or yeast nitrogen base broth (YNB) (Difco, Inc.), depending on which drug was to be studied.

\section{Antifungal agents}

Cilofungin (Lilly Research Laboratories, Indianapolis, IN) was solubilized in $50 \%$ ethanol to give a concentration of 1000 $\mu \mathrm{g} / \mathrm{ml}$. A further dilution was made in either Sabouraud dextrose broth or YNB to give a concentration of $80 \mu \mathrm{g} / \mathrm{ml}$.

Amphotericin B and Flucytosine(Fungizone) (E.R. Squibb \& Sons, Inc., Princeton, $\mathrm{NJ}$ ) was solubilized in sterile distilled water to a concentration of $1000 \mu \mathrm{g} / \mathrm{ml}$ and fur- ther diluted in Sabouraud dextrose broth to a concentration of $20 \mu \mathrm{g} / \mathrm{ml}$.

Flucytosine (Hoffman-LaRoche Inc., Nutley, NJ) was solubilized in sterile $0.9 \%$ saline to give a concentration of $1000 \mu \mathrm{g} / \mathrm{ml}$ and further diluted in YNB broth to a concentration of $20 \mu \mathrm{g} / \mathrm{ml}$.

\section{Susceptibility determinations}

Initial studies were performed to determine the MIC each of the 50 isolates for cilofungin, amphotericin B, and flucytosine. Sabrouraud dextrose broth was used for amphotericin B and FlucytosineMICs; YNB was used for flucytosine MICs. MICs for cilofungin were determined for both media. Initially, $100 \mu \mathrm{l}$ of the broth was added to each well except the first of a 96 well U bottom microtiter plate (Flow Laboratories, Inc., McLean, VA). For cilofungin, $100 \mu$ l of the $80 \mu \mathrm{g} / \mathrm{ml}$ solution was added to the first well of each row, and for amphotericin $B$ and Flucytosineand flucytosine, $100 \mu$ l of the 20 $\mu \mathrm{g} / \mathrm{ml}$ solution was added to the first well of each row. Serial twofold dilutions were made across the plate using a Costar octapette (Costar, Inc., Cambridge, MA). The final well received no drug, serving as a positive growth control. The concentration of cilofungin ranged from $0.04 \mu \mathrm{g} / \mathrm{ml}$ to 40 $\mu \mathrm{g} / \mathrm{ml}$, while that of amphotericin B and flucytosine ranged from $0.01 \mu \mathrm{g} / \mathrm{ml}$ to 10 $\mu \mathrm{g} / \mathrm{ml}$. Each different fungal isolate was added to the 12 wells in a given row so that the final inoculum was $1 \times 10^{3} \mathrm{CFU} /$ well. Plates were incubated for $24 \mathrm{~h}$ at $30^{\circ} \mathrm{C}$. The MIC was determined as the lowest concentration showing no visible turbidity using a microtiter plate reader.

After determining the MIC for each drug for each of the 50 organisms, synergy studies were performed in a similar manner by determining the MIC for each drug in the presence of a constant amount of the other drug added at a concentration four-fold less than the previously determined MIC. The MIC was read in the same manner as described above. 


\begin{tabular}{|c|c|c|c|c|c|c|c|c|c|c|c|}
\hline \multirow{2}{*}{ Organism } & \multicolumn{11}{|c|}{ Cumulative percentage of strains inhibited at indicated concentration $(\mu \mathrm{g} / \mathrm{ml})$} \\
\hline & .04 & .08 & .16 & .31 & .62 & 1.25 & 2.50 & 5 & 10 & 20 & 40 \\
\hline $\begin{array}{l}\text { C. albicans (20) } \\
C F \\
C F+A m B \\
C F \\
C F+5 F C\end{array}$ & & & $\begin{array}{l}25 \\
20\end{array}$ & $\begin{array}{l}55 \\
95\end{array}$ & $\begin{array}{l}100 \\
100\end{array}$ & $\begin{array}{l}10 \\
35\end{array}$ & $\begin{array}{r}95 \\
100\end{array}$ & 100 & & & \\
\hline $\begin{array}{l}\text { C. tropicalis (8) } \\
C F \\
C F+A M B \\
C F \\
C F+5 F C\end{array}$ & & & $\begin{array}{l}25 \\
12\end{array}$ & $\begin{array}{l}37 \\
37\end{array}$ & $\begin{array}{l}62 \\
62 \\
25\end{array}$ & $\begin{array}{l}25 \\
62\end{array}$ & $\begin{array}{l}75 \\
62\end{array}$ & $\begin{array}{l}87 \\
87 \\
75 \\
87\end{array}$ & 87 & 100 & $\begin{array}{l}100 \\
100 \\
100\end{array}$ \\
\hline $\begin{array}{l}\text { C. glabrata (8) } \\
C F \\
C F+A m B \\
C F \\
C F+5 F C\end{array}$ & & & & & & & 12 & $\begin{array}{l}50 \\
87 \\
25\end{array}$ & $\begin{array}{l}100 \\
100 \\
100 \\
100\end{array}$ & & \\
\hline $\begin{array}{l}\text { C. parapsilosis }(8) \\
C F \\
C F+A m B \\
C F \\
C F+5 F C\end{array}$ & & & 12 & $\begin{array}{l}50 \\
12\end{array}$ & $\begin{array}{l}50 \\
12\end{array}$ & & $\begin{array}{l}50 \\
50\end{array}$ & & 75 & $\begin{array}{l}100 \\
100 \\
100 \\
100\end{array}$ & \\
\hline $\begin{array}{l}\text { Candida species }(6)^{*} \\
C F \\
C F+A m B \\
C F \\
C F+5 F C\end{array}$ & & & & & $\begin{array}{l}17 \\
17\end{array}$ & & $\begin{array}{l}50 \\
33 \\
17 \\
33\end{array}$ & $\begin{array}{l}67 \\
50 \\
33\end{array}$ & $\begin{array}{l}67 \\
67 \\
50\end{array}$ & $\begin{array}{l}83 \\
83 \\
83 \\
83\end{array}$ & $\begin{array}{l}100 \\
100 \\
100 \\
100\end{array}$ \\
\hline
\end{tabular}

After reading the MIC for each isolate, $100 \mu \mathrm{l}$ was taken from those wells which showed to turbidity and plated on Sabouraud dextrose agar for assays involving amphotericin B and Flucytosineand on YNB agar for those involving flucytosine. The plates were incubated at $30^{\circ} \mathrm{C}$ for $24 \mathrm{hrs}$ and the minimum fungicidal concentration (MFC) was read as the lowest concentration of drug in which only one or no fungal colonies persisted.

Synergy was defined as a four-fold or greater reduction in the MIC or the MFC for the combination as compared with the value for each drug alone. Antagonism was defined as a four-fold or greater increase in the MIC or MFC for the combination as compared with the value for each drug alone.

\section{Results}

Table 1 shows MICs for cilofungin alone and when combined with either amphotericin B and Flucytosineor flucytosine. In no case was the addition of amphotericin B and Flucytosineto cilofungin synergistic; in only one isolate (C. tropicalis) did the addition of flucytosine to cilofungin produce synergistic inhibition of growth.

Antagonism was also uncommon, occurring only once when flucytosine was added to cilofungin. 


\begin{tabular}{|c|c|c|c|c|c|c|c|c|c|c|c|}
\hline \multirow{2}{*}{ Organism } & \multicolumn{11}{|c|}{ Cumulative percentage of strains inhibited at indicated concentration $(\mu \mathrm{g} / \mathrm{ml})$} \\
\hline & .01 & .02 & .04 & .08 & .16 & .31 & .62 & 1.25 & 2.50 & 5 & 10 \\
\hline $\begin{array}{l}\text { C. albicans (20) } \\
\mathrm{AmB} \\
\mathrm{AmB}+\mathrm{CF} \\
5 \mathrm{FC} \\
5 \mathrm{FC}+\mathrm{CF}\end{array}$ & & 5 & $\begin{array}{l}10 \\
10\end{array}$ & $\begin{array}{r}5 \\
30 \\
25\end{array}$ & $\begin{array}{l}50 \\
50 \\
60 \\
50\end{array}$ & $\begin{array}{r}100 \\
70 \\
60\end{array}$ & 100 & & & & $\begin{array}{l}100 \\
100\end{array}$ \\
\hline $\begin{array}{l}\text { C. tropicalis (8) } \\
A m B \\
A m B+C F \\
5 F C \\
5 F C+C F\end{array}$ & & 12 & 12 & $\begin{array}{l}62 \\
50\end{array}$ & 62 & $\begin{array}{l}50 \\
50 \\
75 \\
75\end{array}$ & $\begin{array}{l}87 \\
75\end{array}$ & $\begin{array}{r}100 \\
87\end{array}$ & 100 & & $\begin{array}{l}100 \\
100\end{array}$ \\
\hline $\begin{array}{l}\text { C. glabrata (8) } \\
A m B \\
A m B+C F \\
5 F C \\
5 F C+C F\end{array}$ & 12 & 50 & $\begin{array}{l}62 \\
37\end{array}$ & $\begin{array}{l}25 \\
75 \\
62\end{array}$ & $\begin{array}{l}25 \\
37 \\
75\end{array}$ & $\begin{array}{r}87 \\
50 \\
100\end{array}$ & $\begin{array}{l}100 \\
100\end{array}$ & & & & 100 \\
\hline $\begin{array}{l}\text { C. parapsilosis (8) } \\
\mathrm{AmB} \\
\mathrm{AmB}+\mathrm{CF} \\
5 \mathrm{FC} \\
5 \mathrm{FC}+\mathrm{CF}\end{array}$ & & $\begin{array}{l}25 \\
12\end{array}$ & $\begin{array}{l}50 \\
25\end{array}$ & $\begin{array}{l}62 \\
50\end{array}$ & $\begin{array}{l}37 \\
87 \\
75\end{array}$ & $\begin{array}{l}75 \\
50 \\
87\end{array}$ & $\begin{array}{l}100 \\
100\end{array}$ & & & & $\begin{array}{l}100 \\
100\end{array}$ \\
\hline $\begin{array}{l}\text { Candida species }(6)^{*} \\
\text { AmB } \\
A m B+C F \\
5 F C \\
5 F C+C F\end{array}$ & & 17 & 50 & $\begin{array}{l}67 \\
33\end{array}$ & 67 & $\begin{array}{l}17 \\
83\end{array}$ & $\begin{array}{r}83 \\
33 \\
100\end{array}$ & $\begin{array}{l}100 \\
100\end{array}$ & 100 & & \\
\hline
\end{tabular}

Table 2 shows MICs for amphotericin and flucytosine when used singly and when combined with cilofungin. Addition of cilofungin to amphotericin B and Flucytosinewas synergistic once (C. glabrata) and antagonistic in 5 strains (2 C. tropicalis isolates, and one each of C. glabrata, C. albicans, and C. parapsilosis). When cilofungin was added to flucytosine, synergism occurred only once (C. albicans) and antagonism occurred 8 times ( 3 C. albicans strains, 2 C. glabrata, one each of $C$. tropicalis, $C$. guilliermondii, and $C$. lusitaniae).

In every instance except one, antagonism and synergism were only four-fold higher or lower than the MIC for the single drug. In that one instance, a strain of $C$. glabrata had a MIC for the combination of flucytosinecilofungin 8-fold greater than that for flucytosine alone.

Table 3 shows MFC's for cilofungin alone and when combined with either amphotericin B and Flucytosineor flucytosine. No synergism with cilofungin-amphotericin B and Flucytosinewas noted, and in only 3 instances (C. tropicalis) was synergism seen with the cilofungin-flucytosine combination. Antagonism, on the other hand, was seen more frequently.

The addition of amphotericin $\mathrm{B}$ and Flucytosineto cilofungin increased the MFC $\geqq$ 4 -fold in 2 C, tropicalis strains and 3 C. albicans strains. The addition of flucytosine to cilofungin was frequently antagonistic, as 


\begin{tabular}{|c|c|c|c|c|c|c|c|c|c|c|c|}
\hline \multirow{2}{*}{ Organism } & \multicolumn{11}{|c|}{ Cumulative percentage of strains at indicated concentration $(\mu \mathrm{g} / \mathrm{ml})$} \\
\hline & .04 & .08 & .16 & .31 & .62 & 1.25 & 2.50 & 5 & 10 & 20 & 40 \\
\hline $\begin{array}{l}\text { C. albicans (20) } \\
C F \\
C F+A m B \\
C F \\
C F+5 F C\end{array}$ & & & & $\begin{array}{r}10 \\
5\end{array}$ & $\begin{array}{l}20 \\
10\end{array}$ & 25 & $\begin{array}{l}20 \\
25\end{array}$ & $\begin{array}{l}80 \\
50\end{array}$ & $\begin{array}{l}90 \\
60\end{array}$ & $\begin{array}{l}15 \\
95 \\
70\end{array}$ & $\begin{array}{l}100 \\
100 \\
100 \\
100\end{array}$ \\
\hline $\begin{array}{l}\text { C. tropicalis (8) } \\
C F \\
C F+A m B \\
C F \\
C F+5 F C\end{array}$ & & & & 12 & $\begin{array}{l}25 \\
12\end{array}$ & $\begin{array}{l}37 \\
25\end{array}$ & $\begin{array}{l}25 \\
50\end{array}$ & 50 & $\begin{array}{l}50 \\
25 \\
62 \\
75\end{array}$ & $\begin{array}{l}62 \\
50\end{array}$ & $\begin{array}{l}100 \\
100 \\
100 \\
100\end{array}$ \\
\hline $\begin{array}{l}\text { C. glabrata }(8) \\
C F \\
C F+A m B \\
C F \\
C F+5 F C\end{array}$ & & & & & & & & & $\begin{array}{l}62 \\
50 \\
50 \\
37\end{array}$ & $\begin{array}{r}100 \\
100 \\
62 \\
100\end{array}$ & 100 \\
\hline $\begin{array}{l}\text { C. parapsilosis (8) } \\
C F \\
C F+A m B \\
C F \\
C F+5 F C\end{array}$ & & & & & & & 25 & 50 & & & $\begin{array}{l}100 \\
100 \\
100 \\
100\end{array}$ \\
\hline $\begin{array}{l}\text { Candida species }(6)^{\star} \\
C F \\
C F+A m B \\
C F \\
C F+5 F C\end{array}$ & & & & & & & & $\begin{array}{l}17 \\
17 \\
17 \\
17\end{array}$ & $\begin{array}{l}50 \\
50\end{array}$ & $\begin{array}{l}50 \\
33\end{array}$ & $\begin{array}{l}100 \\
100 \\
100 \\
100\end{array}$ \\
\hline
\end{tabular}

noted in 7 C. albicans, 1 C. tropicalis, and 1 C. parapsilosis isolates.

Table 4 shows MFCs for amphotericin B and flucytosine when used alone and when cilofungin was added. Addition of cilofungin to amphotericin B and Flucytosinewas synergistic for 5 strains -2 C. tropicalis and 3 C. glabrata. This same combination was antagonistic for 7 strains -3 C. parapsilosis, 2 C. tropicalis, and one each of $C$. albicans and $C$. glabrata. When cilofungin was added to flucytosine, synergism occurred 4 times, in one strain each of C. albicans, C. tropicalis, C. glabrata, and C. krusei. This combination was antagonistic in 16 of the 50 strains $(32 \%)-6$ C. parapsilosis, 4 C. glabrata, and one each of $C$. albicans, C. tropi- calis, C. krusei, C. guilliermondii, C. pseudotropicalis, and C. lusitaniae.

In the 12 instances of synergism noted when MFCs were compared for single vs. two drugs, 7 were only 4-fold decreases in the MFC. Antagonism, which occurred in 37 of the 200 combinations tested, was at the 4-fold level in 18 of the 37 instances.

\section{Discussion}

Cilofungin is a new antifungal agent that has a mechanism of action different from other antifungal agents in that it inhibits synthesis of beta-1,3-glucan leading to cell wall damage (3). It is possible that ci- 


\begin{tabular}{|c|c|c|c|c|c|c|c|c|c|c|c|}
\hline \multirow{2}{*}{ Organism } & \multicolumn{11}{|c|}{ Cumulative percentage of strains at indicated concentration $(\mu \mathrm{g} / \mathrm{ml})$} \\
\hline & .01 & .02 & .04 & .08 & .16 & .31 & .62 & 1.25 & 2.50 & 5 & 10 \\
\hline $\begin{array}{l}\text { C. albicans }(20) \\
A m B \\
A m B+C F \\
5 F C \\
5 F C+C F\end{array}$ & & & & $\begin{array}{r}5 \\
10\end{array}$ & $\begin{array}{l}10 \\
20\end{array}$ & $\begin{array}{r}5 \\
30 \\
30\end{array}$ & $\begin{array}{l}75 \\
60 \\
50 \\
40\end{array}$ & $\begin{array}{r}100 \\
95 \\
45\end{array}$ & & $\begin{array}{r}100 \\
55\end{array}$ & $\begin{array}{l}100 \\
100\end{array}$ \\
\hline $\begin{array}{l}\text { C. tropicalis (8) } \\
\text { AmB } \\
A m B+C F \\
5 F C \\
5 F C+C F\end{array}$ & & & & 12 & 25 & $\begin{array}{l}12 \\
37\end{array}$ & $\begin{array}{l}12 \\
25\end{array}$ & $\begin{array}{c}50 \\
50 \\
37\end{array}$ & $\begin{array}{l}62 \\
62\end{array}$ & $\begin{array}{l}87 \\
75\end{array}$ & $\begin{array}{l}100 \\
100 \\
100 \\
100\end{array}$ \\
\hline $\begin{array}{l}\text { C. glabrata (8) } \\
\text { AmB } \\
A m B+C F \\
5 F C \\
5 F C+C F\end{array}$ & & & $\begin{array}{l}25 \\
12\end{array}$ & 50 & $\begin{array}{l}37 \\
62 \\
37\end{array}$ & $\begin{array}{l}75 \\
50\end{array}$ & $\begin{array}{l}25 \\
62\end{array}$ & $\begin{array}{l}50 \\
75\end{array}$ & $\begin{array}{l}87 \\
87\end{array}$ & 100 & $\begin{array}{l}100 \\
100 \\
100\end{array}$ \\
\hline $\begin{array}{l}\text { C. parapsilosis (8) } \\
A m B \\
A m B+C F \\
5 F C \\
5 F C+C F\end{array}$ & & & 12 & 37 & $\begin{array}{l}50 \\
12\end{array}$ & $\begin{array}{l}87 \\
37\end{array}$ & $\begin{array}{l}12 \\
12 \\
50\end{array}$ & $\begin{array}{l}37 \\
75\end{array}$ & $\begin{array}{l}75 \\
25 \\
87\end{array}$ & $\begin{array}{r}100 \\
50\end{array}$ & $\begin{array}{l}100 \\
100 \\
100\end{array}$ \\
\hline $\begin{array}{l}\text { Candida species }(6)^{*} \\
\text { AmB } \\
\mathrm{AmB}+\mathrm{CF} \\
5 F C \\
5 F C+C F\end{array}$ & & & 17 & 33 & & $\begin{array}{l}50 \\
17\end{array}$ & $\begin{array}{l}17 \\
50\end{array}$ & $\begin{array}{l}67 \\
33 \\
67\end{array}$ & $\begin{array}{l}67 \\
83 \\
83\end{array}$ & 83 & $\begin{array}{l}100 \\
100 \\
100 \\
100\end{array}$ \\
\hline
\end{tabular}

lofungin might act synergistically with other antifungal agents, especially flucytosine, which acts, not on the cell wall, but at the level of DNA replication (5). Although it is possible to get synergistic action with two agents active at the level of the cell wall and cell membrane, such as cilofungin and amphotericin B, it seems less likely that this combination will result in synergism.

We found that, indeed, cilofungin added to amphotericin B and Flucytosineshowed only minimal synergistic inhibition or killing of any of the Candida species tested. When the corresponding studies were performed, which looked at the effect of subinhibitory concentrations of amphotericin
$B$ added to cilofungin, synergy did not occur in any strain tested.

We also found that synergistic inhibition or killing of Candida strains was rarely noted with the combination of cilofungin and flucytosine. In fact, antagonism was quite common with this combination. In no instance did a resistant strain become susceptible to cilofungin or flucytosine when the second drug was added.

The usefulness of cilofungin in Candida infections is not known at this time. It would appear to be active against $C$. albicans and $C$. tropicalis by in vitro tests $(2,3$, 7 ). We could not verify by our in vitro assays a potential role for combination therapy with amphotericin B-cilofungin or flu- 
cytosine-cilofungin. However, studies comparing cilofungin alone with combination therapy in experimental Candida infections could possibly show an in vivo synergistic effect not detected by in vitro assays.

Acknowledgements: This study was supported by the Veterans Administration Research Service.

\section{References}

1. Bennett, J.E., W.E. Dismukes, R.J. Duma, et al (1979): A comparison of amphotericin B and Flucytosinealone and combined with flucytosine in the treatment of cryptococcal meningitis. $\mathrm{N}$. Engl. J. Med. 301, 126-131.

2. Bulo, A.N., S.F. Bradley and C.A. Kauffman (1988): Susceptibility of yeast-like fungi to a new antifungal agent, LY 121019. Mycoses 31, $330-333$.

3. Gordee, R.S., D.J. Zeckner, L.F. Elis, A.L. Thakkar and L.C. Howard (1984): In vitro and in vivo anti-Candida activity and toxicology of LY 121019. J. Antibiotics 37, 1054-1065.
4. Hobbs, M, J. Perfect and D. Durack (1988): Evaluation of in vitro antifungal activity of LY 121019. Eur. J. Clin. Microbiol. Infect. Dis. 7, $77-80$.

5. Kauffman, C.A. (1988): Flucytosine. In: Antimicrobial Agents Annual, 3. J. Verhoef and P.K. Peterson, editors. Elsevier Science Publishers BV, Amsterdam, pp 246-250.

6. Medoff, G. and G.S. Kobayashi (1980): Strategies in the treatment of systemic fungal infections. N. Engl. J. Med. 302, 145-155.

7. Melchinger, W. and J. Müller (1987): Studies on the in vitro sensitivity of yeast strains isolated from clinical specimens to LY 121019, a new antifungal agent. Mykosen 30, 605-608.

8. Spitzer, E.D., S.J. Travis and G.S. Kobayashi (1988): Comparative in vitro activity of LY 121019 and amphotericin B and Flucytosineagainst clinical isolates of Candida species. Eur. J. Clin. Microbiol. Infect. Dis. 7, 80-81.

Correspondence:

Prof. Dr. Carol A. Kauffman,

VA Medical Center, 2215 Fuller Road, Ann Arbor, Michigan 48105, U.S.A. 